\title{
Effects of dormancy-breaking methods on germination of the water- impermeable seeds of Gleditsia caspica (Fabaceae) and seedling growth
}

\author{
Kazem Nourmohammadi $^{1}$, Davoud Kartoolinejad ${ }^{2 *}$, Reza Naghdi ${ }^{3}$, Carol C. Baskin ${ }^{4}$
}

${ }^{1}$ Young Researchers and Elite Club, Khorramabad Branch, Islamic Azad University, Khorramabad, Iran

${ }^{2}$ Department of Arid Land Forestry, Faculty of Desert Studies, Semnan University, Semnan, Iran

${ }^{3}$ Department of Engineering of Wood and Paper Industries, Faculty of Natural Resources, Semnan University,

Semnan, Iran

${ }^{4}$ Department of Biology, University of Kentucky, Lexington, Kentucky 40506, USA and Department of Plant and Soil Sciences, University of Kentucky, Lexington, Kentucky 40546, USA

\begin{abstract}
Nourmohammadi, K., Kartoolinejad, D., Naghdi, R., Baskin, C.C., 2019. Effects of dormancy-breaking methods on germination of the water-impermeable seeds of Gleditsia caspica (Fabaceae) and seedling growth. Folia Oecologica, 46: 115-126.
\end{abstract}

\begin{abstract}
Various treatments can be used to break physical dormancy (PY, i.e. water-impermeable seed coat) of legume species, but the effects of these treatments on seedling growth are of great importance in the success of afforestation projects. Our aims were to determine the effects of 20 PY-breaking treatments on (1) germination of Gleditsia caspica (Caspian locust) seeds and (2) seedling growth. Five germination and nine seedling growth and morphological traits were studied. Immersion in concentrated sulfuric acid (98\%) for 60 minutes was optimal for all germination traits and for all seedling traits except root length. After seed coat removal or treatment with sulfuric acid (for 45 to 120 minutes), $99-100 \%$ of the seeds germinated, but seedling growth traits after 5 months were significantly lower in the former than in the latter treatment. Other treatments (e.g., different periods of exposure to cold water, boiling water, and KNO3) did not significantly increase germination or improve seedling growth. Thus, despite incurring adverse environmental impacts, sulfuric acid treatments have the best potential to break seed dormancy and produce high-quality seedlings (in terms of shoot length, root and shoot mass, root area, leaf number and area and collar diameter) of Caspian locust.
\end{abstract}

\section{Keywords}

fresh biomass, root area, seed dormancy breaking, seedling growth, sulfuric acid

\section{Introduction}

Most temperate-zone legume species have a water-impermeable seed coat (Hu et al., 2009) that results in physical dormancy (PY); therefore, special pre-treatments are required to promote germination. That is, seed germination percentages may be low, irregular, and prolonged unless a treatment is given to make the seed coat water-permeable
(MiYase et al., 2010; BabashPOUR et al., 2011; Soltani et al., 2016). Under natural conditions, this impermeability may decrease gradually, so that a certain percentage of seeds germinates in each germination season. To enhance germination percentages of economically-important species, various pre-treatments are applied, e.g., piercing, nicking, chipping and filing or treatment with hot water treatment or acid (SozZI and CHIESA, 1995; BASKIN and

*Corresponding author:

e-mail: kartooli58@semnan.ac.ir 
BASKIN, 2004; Hu et al., 2009). In nature, seeds become water-permeable in response to signals from the environment, especially temperature and moisture that cause the water gap on the seed coat to open (BASKIN and BASKIN, 2004).

In Iran, Hyrcanian forests, ranging from 15 to over 2,800 $\mathrm{m}$ asl, occur on the northern slopes of the Alborz mountain range, and they are the most important ArctoTertiary relict forests in western Eurasia. These forests have a very rich biodiversity including endemic tree species such as Parrotia persica, Gleditsia caspica, Populus caspica, Pterocarya fraxinifolia, Albizia julibrissin, Buxus hyrcania, and Acer velutinum. Hyrcanian forests have survived since the last glacial period and are valuable in terms of genetic resources. Presently, some areas of these forests located on the plains have been harshly manipulated and destroyed by human activities, thus only some small areas of the once abundant Hyrcanian forests remain today (Scharnweber et al., 2007; KartoolineJAD et al., 2007; Hosseini et al., 2008; YousEFZADEH et al., 2017).

One of the pioneer and highly important species of these forests on plain areas is Gleditsia caspica Desf. (Caspian locust) that has the potential to fix soil nitrogen. G. caspica is a deciduous leguminous tree that grows in temperate lowlands forests on the southern coast of the Caspian Sea in northern Iran. It is commonly found from sea level to $500 \mathrm{~m}$ asl and does not occur in the Eastern Hyrcanian forests and north-eastern Alborz Mountains (Scharnweber et al., 2007). Excessive felling of Caspian locust trees for rural consumption, cattle grazing, and also conversion of forest lands to residential areas and farm land have led to the destruction of the natural habitats of this species. Therefore, today it is only found as individual stems and/or in small communities around row-crop and cattle farms (SCHNABEL and KRUTOVSKII, 2004; NourmoHAMMADI et al., 2016). Given the high value of this pioneer species of the Hyrcanian forests, conservation of its natural habitats seems to be indispensable. However, due to its impermeable seed coat little regeneration from seeds occurs in natural sites. Thus, seedling production and establishment through afforestation programs are needed to conserve this endemic species.

Seeds of Gleditsia sp., as is true for many legumes, have PY. Generally, various physical and chemical treatments such as hot water, sulfuric acid, nitric acid, mechanical scratching, and seed coat removal are applied to make seeds with PY water-permeable (BASKIN and BASKIN, 2004; Hu et al., 2009). Although Caspian locust is a pioneering and highly tolerant species of the Hyrcanian plain and lowland forests and is commonly the first tree species to appear after the these forests are degraded, it has not been used in afforestation of degraded Hyrcanian lands. In spite of the critical role, values, and the abundant applications of Caspian locust, there is scanty information on its seedling production and seed germination. NouRMOHAMмADI et al. (2016) investigated the effects of seed dormancy breaking treatments on seedling quality indices, e.g., sturdiness quotient (SQ), shoot/root dry weight ratio (SRR) and Dickson's seedling quality index (DQI), and discussed the interrelations of germination percentage and mean time with the given indices. ZoGHI et al. (2011) studied the effects of seven seed dormancy breaking treatments on Caspian locust and reported that concentrated sulfuric acid treatment (90 minutes) was the most suitable method to obtain maximal germination (about 38\%). The existing archival publications show that there is almost no information on the effects of physical and chemical seed dormancy breaking treatments both on germination traits at the initial stage of growth (e.g., seed vigor index, germination rate and percentage, and root and shoot length) and on morphological and growth traits of the produced seedling at further growth stages (e.g., seedling root and shoot length, root and shoot mass, root area, leaf number and area, and collar diameter). Therefore, the aim of this research was evaluate the effects of 20 physical and chemical treatments (commonly used for breaking PY) on germination traits and seedling growth of Caspian locust. Our hypothesis was that some methods of dormancy break do not result in the production of high quality seedlings with the growth and morphological characteristics that would help ensure successful afforestation of degraded Hyrcanian lands. To address this hypothesis, we asked the following questions:

- What are the most efficient dormancy-breaking treatments for high germination percentages, rate, seed vigor index, and root and shoot length of Caspian locust seeds?

- How do the different dormancy-breaking treatments affect seedling growth and morphology of Caspian locust?

\section{Materials and methods}

\section{Study species, study area, and seed collection}

Caspian locust is characterized by its broadly expanded crown, pinnate leaves $10-25 \mathrm{~cm}$ in length with $12-20$ ellipse leaflets that are $2-5 \mathrm{~cm}$ in length, and its pods are long, nearly straight or fairly fusiform with $15-25 \mathrm{~cm}$ length and $3 \mathrm{~cm}$ width. 9-15 seeds compactly located in pods are smooth brown, $10 \mathrm{~mm}$ in length and $7 \mathrm{~mm}$ wide. On the trunk and stem there are straight thorns 15 $\mathrm{cm}$ in length. The leaves of this summer-flowering tree develop in spring, and the grey pods mature in late summer and early autumn (RECHINGER, 1986; SCHNABEL and KrutovskiI, 2004; Miyase et al., 2010; Zarinjoei et al., 2014; Nourmohammadi et al., 2016). The wood is very hard and is used in rural areas as the base of buildings and rice barns. The green fruit is used by villagers as forage for beef cattle in summer, and its ripped fruits and bark are used as a part of livestock forage in winter (SCHNABEL and KRUTOVSKII, 2004; Nourmohammadi et al., 2016).

Mature healthy fruits of Caspian locust were collected from Kashpel Forest Park, located in Mazandaran Province, northern Iran in spring 2012 (36 $28^{\prime} 32^{\prime}$ 'N, $\left.52^{\circ} 5^{\prime} 20^{\prime \prime} \mathrm{E}\right)$. Annual precipitation in this part of the Hyrcanian forests is $689 \mathrm{~mm}$ with the highest and lowest amounts occurring in October (163.4 mm) and July (29 
$\mathrm{mm})$, respectively. Mean annual temperature is $14.5{ }^{\circ} \mathrm{C}$ and the coldest and hottest months are December $\left(3^{\circ} \mathrm{C}\right)$ and July $\left(29.7^{\circ} \mathrm{C}\right)$, respectively.

Initial moisture content of the collected seeds was $3.08 \%$ (calculated based on equation 1 ), and the number of pure seeds per kilogram was 6,320 (IsTA, 2009).

$$
\operatorname{Smc}(\%)=\frac{S f w-S d w}{S d w} \times 100
$$

where $S m c$ is Seed moisture content, $S f w$ is Seed fresh weight, $S d w$ is Seed dry weight.

\section{Assessment of seeds' viability}

For investigating seeds' viability, one hundred seeds were soaked in tap water for about $48 \mathrm{~h}$, in order to seed coat to be easily removed. After accurately pulling the embryo and cotyledons out of the seed and removing the excess water, they were incubated within $1 \%$ Tetrazolium solution at $30{ }^{\circ} \mathrm{C}$ for $48 \mathrm{~h}$ in dark conditions. While the pink pigments were completely developed through the seeds, they were washed twice with distilled water, and finally investigated under a binocular.

\section{Effect of PY-breaking treatments on germination}

The effects of physical and chemical treatments on breaking the PY of Caspian locust seeds were investigated under laboratory conditions, using 20 treatments known to make seeds with PY water permeable (NourmoHAmmADI et al., 2016; Yousefr et al., 2017b): $\mathrm{T}_{0}$ : control; $\mathrm{T}_{1}-\mathrm{T}_{6}$ : soaking in tap water for $1,2,3,4,5$, and 6 days, at room temperature $\left(\approx 25^{\circ} \mathrm{C}\right) ; \mathrm{T}_{7}-\mathrm{T}_{9}$ : soaking in hot water 40,80 , and $100{ }^{\circ} \mathrm{C}$ that was allowed to be cool gradually to room temperature; $\mathrm{T}_{10}$ : seeds coat removal (by scalper); $\mathrm{T}_{11}-\mathrm{T}_{14}$ : immersion in $\mathrm{KNO}_{3}(1 \%)$ for $12,24,48$ and 72 hours; $\mathrm{T}_{15}-\mathrm{T}_{21}$ : immersion in $\mathrm{H}_{2} \mathrm{SO}_{4}(98 \%)$ for $15,30,45,60,90,120$, and 150 minutes.

There were four replicates of 25 seeds each for each treatment, and seeds were placed in $10 \mathrm{~cm}$-diameter Petri dishes on paper moistened with distilled water. Seeds were incubated at $20^{\circ} \mathrm{C}$ at a $16 \mathrm{~h}$ light $(1,000$ lux fluorescent light) / $8 \mathrm{~h}$ dark regime. The seeds were kept moist during the germination. The presence of a $2-\mathrm{mm}$ length radicle was the criterion for germination during the 6-week period of monitoring. The main germination parameters calculated according to the following equations (RAHIMI et al., 2016; Yousefi et al., 2017a; Ista Rules, 2009).

$$
\begin{array}{rlr}
\text { Germination percentage } & =\left(\frac{n}{N}\right) \times 100 & \text { Eq. (2) } \\
\text { Germination rate } & =\sum \frac{n_{i}}{t_{i}} & \text { Eq. (3) }
\end{array}
$$

Seed vigor index $=G P(\%) \times$ Mean $(S l+R l)$ Eq. (4)

where $n$ is number of germinated seeds, $n_{i}$ is number of germinated seeds between recording intervals, $N$ is total number of seeds, $t_{i}$ is number of days since the test was started, $S l$ is shoot length, and $R l$ is root length.

\section{Seedling growth after dormancy break}

After recording germination data each day, new-germinated seedlings were transferred to the greenhouse located in the Hyrcanian lowland temperate forests of northern Iran (altitude $129 \mathrm{~m}$ asl). The highest and lowest temperatures in the greenhouse during the spring and summer were $36.2{ }^{\circ} \mathrm{C}$ and $20.2^{\circ} \mathrm{C}$, respectively, with a relative humidity about 50\%. Randomized Complete Block Design (RCBD) was considered for this experiment. There were 20 treatments (including one control) with three replications for each treatment. For each replication, six seedlings were planted individually in polybags $(10 \times 10 \mathrm{~cm})$ containing a mixture of forest soil, coarse sand and fine sand in a 3:1:1 ratio. As this species was considered to be shade intolerant, the polybags were placed under full light in a greenhouse bed and irrigated manually every 2 days for a period of 150 days, after which growth performance was evaluated.

\section{Seedling growth performance}

The following measurements were made for each seedling: collar diameter, total number of leaves, shoot and root length, shoot and root dry mass and leaf and root area. Shoot and root dry mass were measured after oven-drying of fresh materials for $48 \mathrm{~h}$ in $60{ }^{\circ} \mathrm{C}$ temperature and collar diameters of seedlings measured using a vernier caliper. Leaf and root area were measured using a Leaf Area Meter Model CI 202 (CID Inc., USA). Also, Dickson's Quality Index was calculated based on equation 5 (DICKSON et al., 1960).

$$
\text { Quality index }=\frac{S d w(g)}{\frac{H(c m)}{R c d(m m)}+\frac{S d w(g)}{R d w(g)}}
$$

where $S d w(\mathrm{~g})$ is Seedling dry weight, $H$ is Height, $R d w$ $(\mathrm{mm})$ is Root collar diameter $(\mathrm{mm}), S d w(\mathrm{~g})$ is Shoot dry weight $(\mathrm{g})$, Rdw $(\mathrm{g})$ is Root dry weight $(\mathrm{g})$.

\section{Data analysis}

Data were analyzed using a completely randomized design. Normality of the data and homogeneity of variances were checked using the Kolmogorov-Smirnov and the Levene test, respectively. Then, analysis of variance (ANOVA) was run to determine if there were significant differences among treatments. The mean comparison was conducted using Tukey's HSD test. All statistical tests were carried out in SPSS software.

\section{Results}

\section{Effect of different dormancy breaking treatments on germination characteristics}

The seeds of Caspian locust tested for germination immediately after they were separated from the fruits germinated to only $4 \%$, but seed viability (Tetrazolium test) 
was $100 \%$. Thus, $96 \%$ of the seeds were dormant (Table 1). Immersion of seeds in cold water for 1 to 6 days and in $\mathrm{KNO}_{3}$ solution for $12,24,48$, and 72 hours did not significantly increase the germination percentage or rate. Among the hot water treatments, the highest $(77.3 \%)$ and lowest $(4.0 \%)$ germination was observed in $\mathrm{T}_{9}\left(100^{\circ} \mathrm{C}\right)$ and $\mathrm{T} 7$ $\left(40{ }^{\circ} \mathrm{C}\right)$ treatments, respectively. Sulfuric acid and seed coat removal treatments were the most effective in increasing germination percentages (Table 1).

The $\mathrm{T}_{0}$ treatment (control) had a very low seed vigor index (2.34), and the highest and the lowest seed vigor indices were for seeds in the $\mathrm{T}_{18}(56.42)$ and $\mathrm{T}_{14}(1.50)$ treatments, respectively (Table 1). Cold water and $\mathrm{KNO}_{3}$ treatments not only did not increase seed vigor index, but in some cases they led to a reduction of seed vigor index compared to that of the control (e.g., $\mathrm{T}_{3}, \mathrm{~T}_{5}$, and $\mathrm{T}_{14}$ ). Lower water temperatures (up to $40^{\circ} \mathrm{C}$ ) had no significant effect on enhancing seed vigor index (vs. the control), but as water temperature was increased to $100{ }^{\circ} \mathrm{C}$ (boiling), the given index increased significantly. Seed coat removal and immersion in concentrated sulfuric acid treatments did not show a significant impact on seed vigor index, and as the immersion time increased from 30 to 150 minutes $\left(\mathrm{T}_{16}-\mathrm{T}_{21}\right)$ the mentioned index showed an outstanding improvement.

There was a positive and significant relationship between seed immersion time in sulfuric acid and germination rate, such that increasing the immersion time from 15 to 30 minutes improved germination rate from 2.55 to 9.34 , respectively (Table 1). A further increase in immersion time up to 150 minutes resulted in the maximum germination rate (19.63).

Seed coat removal enhanced seed germination rate from 0.2 to 12.5 seed per day. Increase in temperature of the hot water from 40 to $100{ }^{\circ} \mathrm{C}$ improved seed germination rate from 0.19 to 5.64 seed per day. However, cold water and $\mathrm{KNO}_{3}$ treatments did not have a significant effect on germination rate, and only seed immersion in cold water for 6 days improved germination time to $1.63 \mathrm{seed}$ per day.

\section{Seedling growth after dormancy break}

The best effect on seedling growth of the PY-breaking treatments on Caspian locust seeds was improved seedling radicle length, the highest of which was for seedlings resulting from seeds treated with cold water $\left(\mathrm{T}_{5}, \mathrm{~T}_{1}\right.$, and $\left.\mathrm{T}_{2}\right)$. The lowest radical length was for seeds treated with sulfuric acid, and the other physical treatments had no significant effects. The differences of shoot length of seedlings from seeds receiving various treatments were not significant. However, seedlings from seeds acid scarified for 60 min had the greatest average of shoot length (Table 1).

\section{Seedling growth performance Dickson's Quality Index}

Cold water, $\mathrm{KNO}_{3}$, and hot water treatments (vs. control treatment) did not have a significant effect on improving seedling quality index. The lowest seedling quality index (0.1) was for seedlings from seeds soaked in water for 2 days ( $\mathrm{T}_{2}$ treatment), and the index increased to 0.31 when soaking time in water was increased to 4 days. This value was then reduced to 0.16 and 0.12 after seeds soaked for 5 and 6 days, respectively. Also, seed immersion in hot water at $80^{\circ} \mathrm{C}$ and $100^{\circ} \mathrm{C}$ improved seedling quality index from 0.2 to 0.35 and to 0.31 , respectively. Sulfuric acid treatment proved to be the most efficient in improving the seedling quality index amongst all the applied treatments, with an increase in immersion times resulting in enhanced seedling quality index. Maximal seedling quality indices were 0.61 and 0.60 after 60 and 120 min of acid scarification, respectively. Immersion for very short (15 minutes) and very long (150 minutes) times resulted in reduced seedling quality index, but in general these treatments were not significantly different from the control in terms of their effect on seedling quality index (Table 2).

\section{Shoot and root mass}

In terms of seedling shoot biomass, $\mathrm{T}_{16}, \mathrm{~T}_{18}$, and $\mathrm{T}_{20}$ treatments resulted in the highest values of $1.39,1.38$, and 1.38 gram, respectively, and $\mathrm{T}_{10}$ the lowest $(0.1 \mathrm{~g})$. For seedling root biomass production, $\mathrm{T}_{16}, \mathrm{~T}_{18}$, and $\mathrm{T}_{20}$ treatments, had the highest values of $2.10,2.07$, and 2.02 gram, respectively, and $\mathrm{T}_{2}$ the lowest $(0.19 \mathrm{~g})$. The physical treatments along with the different levels of $\mathrm{KNO}_{3}$ treatment showed either lower or slightly higher values of root biomass as compared to those of the control (Table 2).

\section{Growth performance (shoot/root length and collar di- ameter)}

The seedlings from seeds treated with different levels of sulfuric acid $\left(\mathrm{T}_{16}, \mathrm{~T}_{20}\right.$, and $\left.\mathrm{T}_{18}\right)$ for different periods of time had the greatest shoot length. The shortest length $(3.03 \mathrm{~cm})$ was for seedlings from seeds with the seed coat removed. The longest seedling root length was recorded for the control treatment $(15.84 \mathrm{~cm}$ at maximum), while seedlings from seeds dipped into boiling water and those receiving $\mathrm{KNO}_{3}$ or sulfuric acid treatments for different periods of time had the same length. However, the shortest lengths were observed in $\mathrm{T}_{6}$ and $\mathrm{T}_{10}$ treatments (Table 2).

Different levels of sulfuric acid treatment $\left(\mathrm{T}_{16}, \mathrm{~T}_{20}\right.$, and $\mathrm{T}_{18}$ ) resulted in seedlings with a collar diameter of $3.16,3.14$, and $3.13 \mathrm{~mm}$, respectively, which were the best treatments among all those applied. Collar diameter (2.04 $\mathrm{mm}$ ) was lowest for seedlings from seeds with the seed coat removed, and that for seedlings from other seed treatments did not differ significantly from the control (Fig. 1).

\section{Leaf number, leaf area and root area}

The largest mean number of leaves per seedling was for those derived from seeds treated for different periods of time with sulfuric acid $\left(\mathrm{T}_{18}\right.$ and $\left.\mathrm{T}_{20}\right)$, while the smallest number was observed in the $T_{7}$ (3.67) treatment. Different periods of $\mathrm{KNO}_{3}$ treatment, as well as the other physi- 


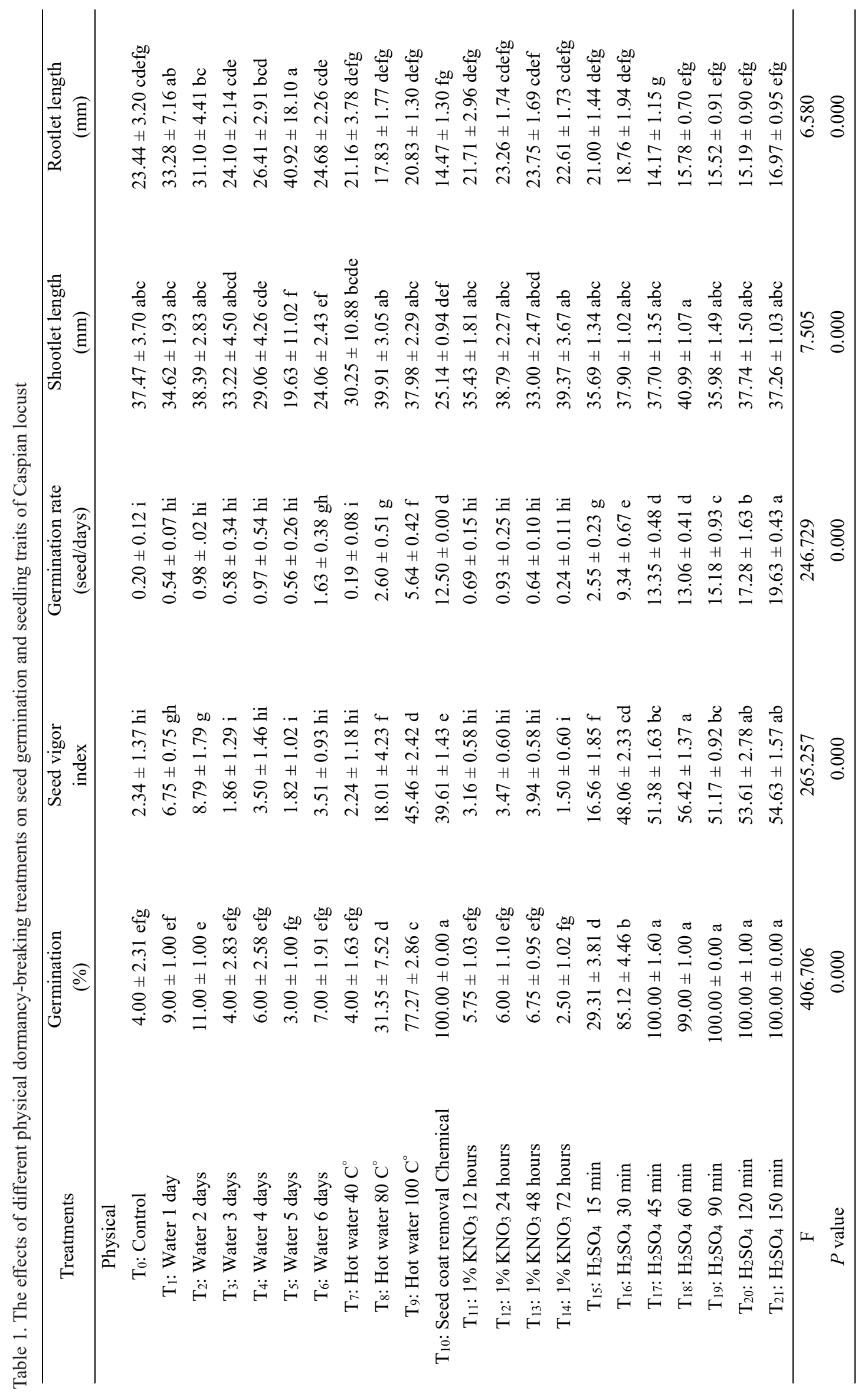




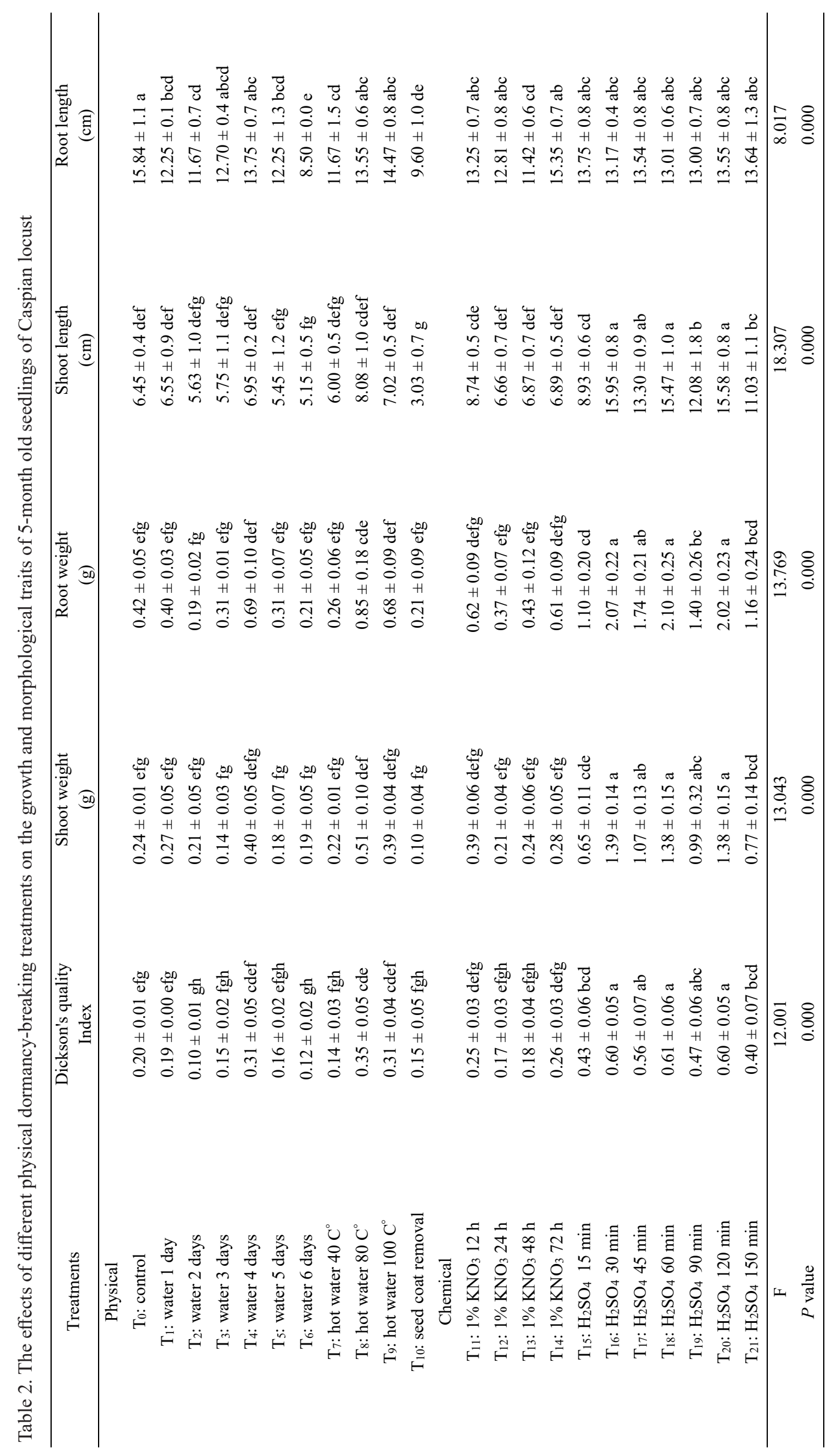




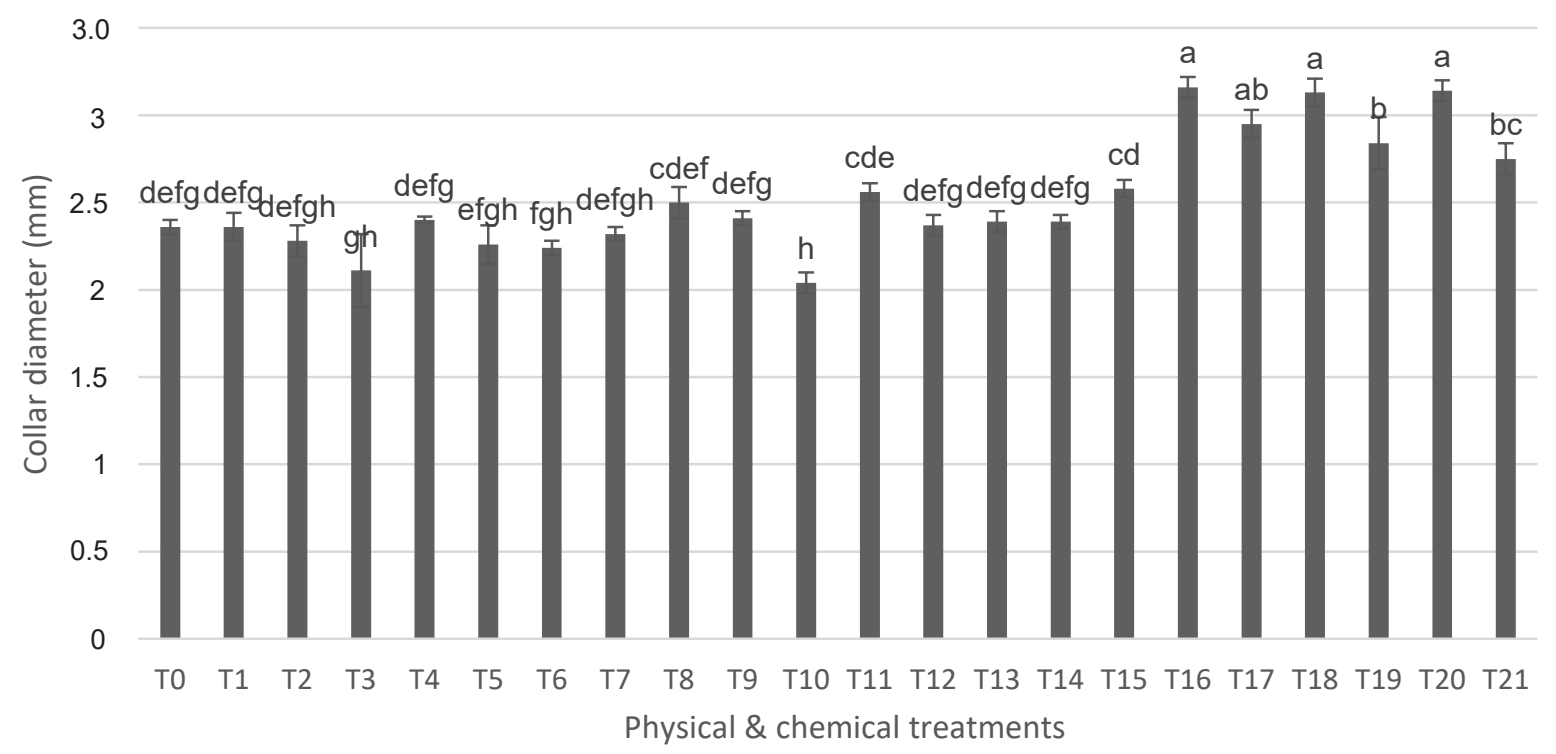

Fig. 1. Effects of different seed treatments on stem collar diameter of 5-month old seedlings of Gleditsia caspica. $\mathrm{T}_{0}$ : control; $\mathrm{T}_{1}-\mathrm{T}_{6}$ : soaking in tap water for 1 to 6 days; $\mathrm{T}_{7}-\mathrm{T}_{9}$ : soaking in hot water 40,80 , and $100{ }^{\circ} \mathrm{C} ; \mathrm{T}_{10}$ : seeds coat removal; $\mathrm{T}_{11}-\mathrm{T}_{14}$ : immersion in $\mathrm{KNO}_{3}(1 \%)$ for 12, 24, 48 and 72 hours; $\mathrm{T}_{15}-\mathrm{T}_{21}$ : immersion in $\mathrm{H}_{2} \mathrm{SO}_{4}(98 \%)$ for $15,30,45,60,90,120$, and 150 minutes, respectively.

cal treatments, showed mean values close to those of the control (Fig. 2). Considering leaf area and root area, the highest values were observed in seedlings from seeds in the $\mathrm{T}_{18}\left(15.27 \mathrm{~cm}^{2}\right)$ and $\mathrm{T}_{20}\left(14.61 \mathrm{~cm}^{2}\right)$ treatments and the lowest for $\mathrm{T}_{3}\left(3.83 \mathrm{~cm}^{2}\right)$. Different periods of cold water and $\mathrm{KNO}_{3}$ treatments had mean values close to those of the control. $\mathrm{T}_{18}, \mathrm{~T}_{16}$, and $\mathrm{T}_{20}$ treatments of seeds resulted in seedling leaf areas of $26.59,24.8$, and $23.95 \mathrm{~cm}^{2}$, respectively, which were the highest, while $\mathrm{T}_{10}$ showed a minimal effect $\left(2.11 \mathrm{~cm}^{2}\right)$ on leaf area (Fig. 3 and 4$)$.

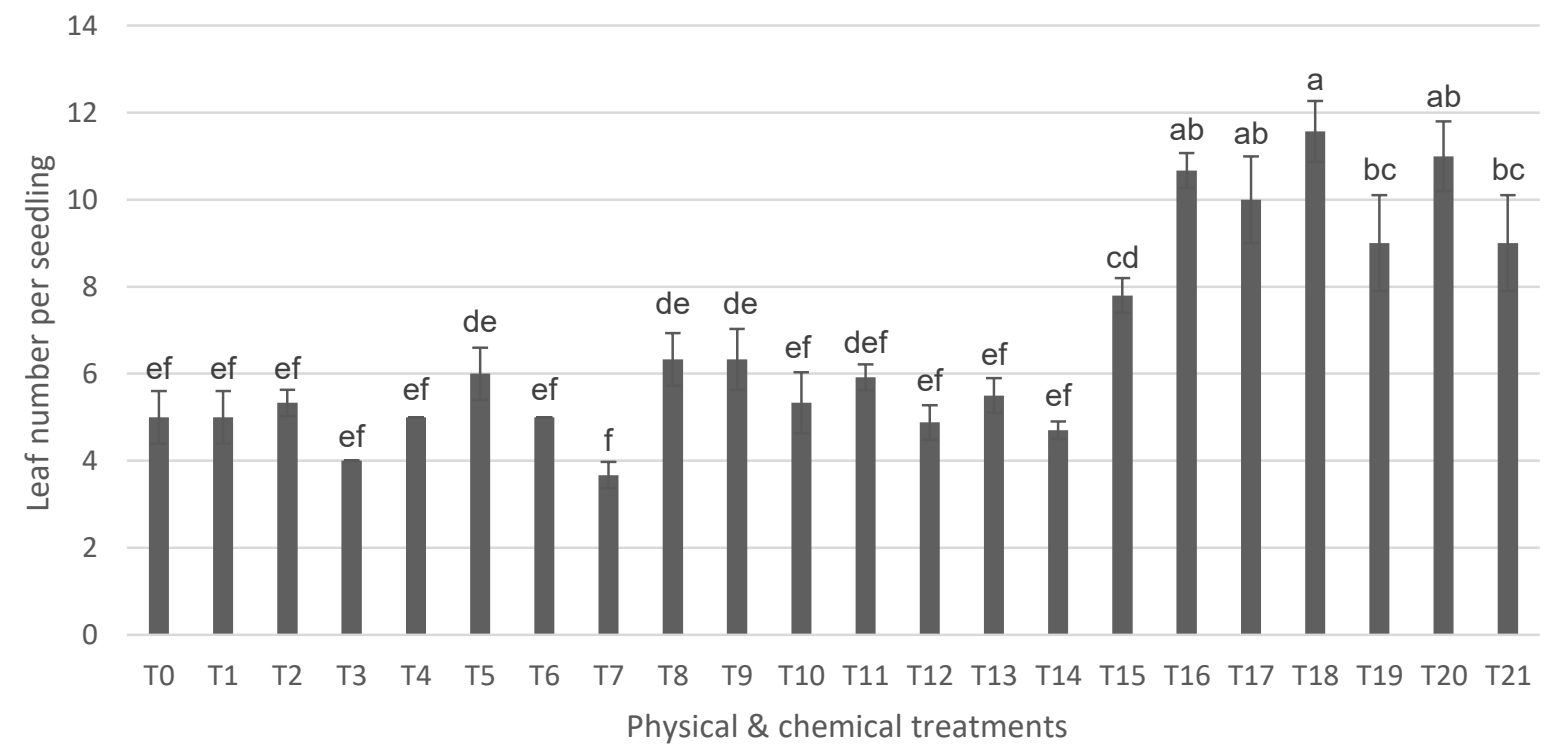

Fig. 2. Effects of different seed treatments on leaf number of 5-month old seedlings of Gleditsia caspica. $\mathrm{T}_{0}$ : control; $\mathrm{T}_{1}-$ $\mathrm{T}_{6}$ : soaking in tap water for 1 to 6 days; $\mathrm{T}_{7}-\mathrm{T}_{9}$ : soaking in hot water 40,80 , and $100{ }^{\circ} \mathrm{C} ; \mathrm{T}_{10}$ : seeds coat removal; $\mathrm{T}_{11}-\mathrm{T}_{14}$ : immersion in $\mathrm{KNO}_{3}(1 \%)$ for 12, 24, 48 and 72 hours; $\mathrm{T}_{15}-\mathrm{T}_{21}$ : immersion in $\mathrm{H}_{2} \mathrm{SO}_{4}(98 \%)$ for $15,30,45,60,90,120$, and 150 minutes, respectively. 


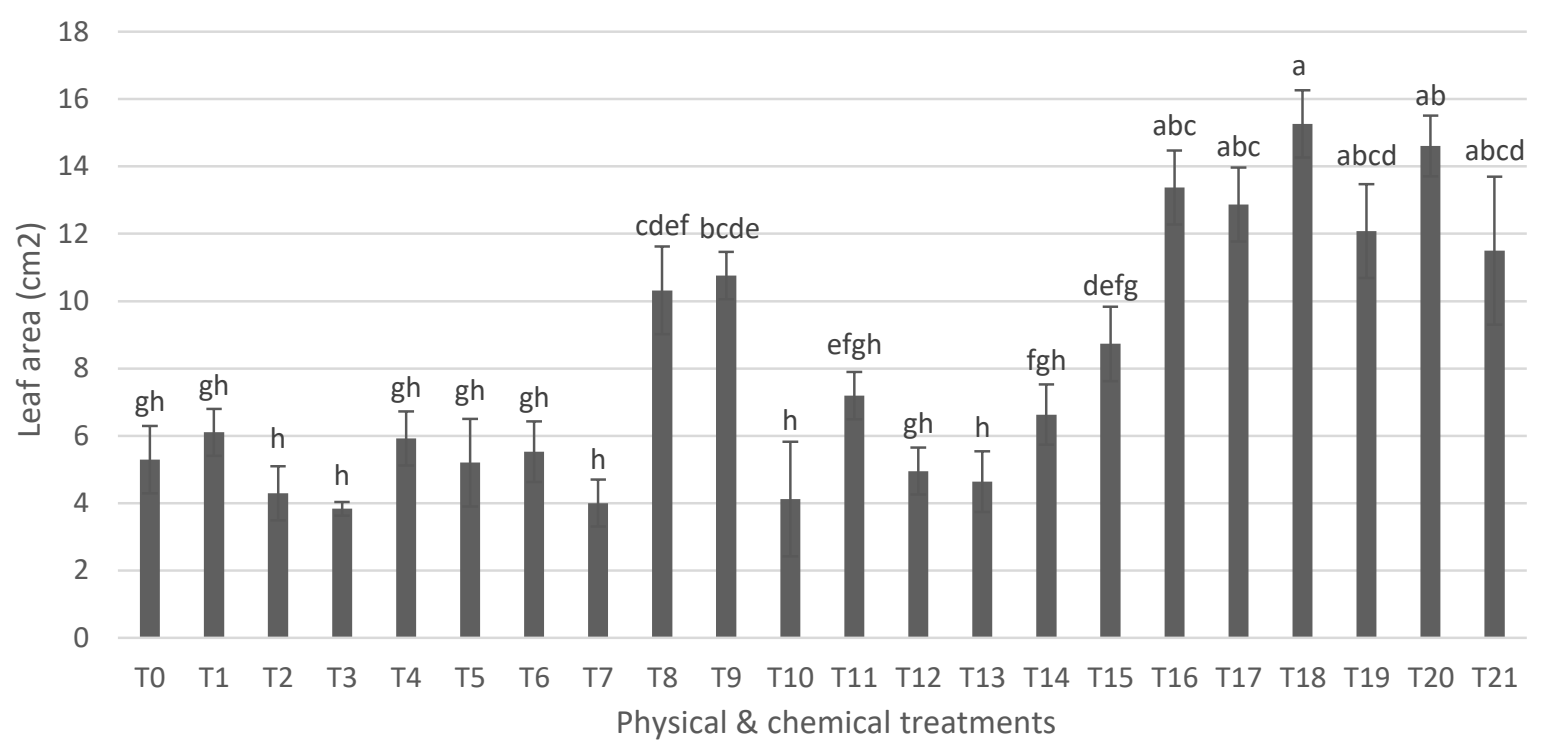

Fig. 3. Effects of different seed treatments on leaf area of 5-month old seedlings of Gleditsia caspica. $\mathrm{T}_{0}$ : control; $\mathrm{T}_{1}-\mathrm{T}_{6}$ : soaking in tap water for 1 to 6 days; $\mathrm{T}_{7}-\mathrm{T}_{9}$ : soaking in hot water 40,80 , and $100{ }^{\circ} \mathrm{C}$; $\mathrm{T}_{10}$ : seeds coat removal; $\mathrm{T}_{11}-\mathrm{T}_{14}$ : immersion in $\mathrm{KNO}_{3}(1 \%)$ for $12,24,48$ and 72 hours; $\mathrm{T}_{15}-\mathrm{T}_{21}$ : immersion in $\mathrm{H}_{2} \mathrm{SO}_{4}(98 \%)$ for $15,30,45,60,90,120$, and 150 minutes, respectively.

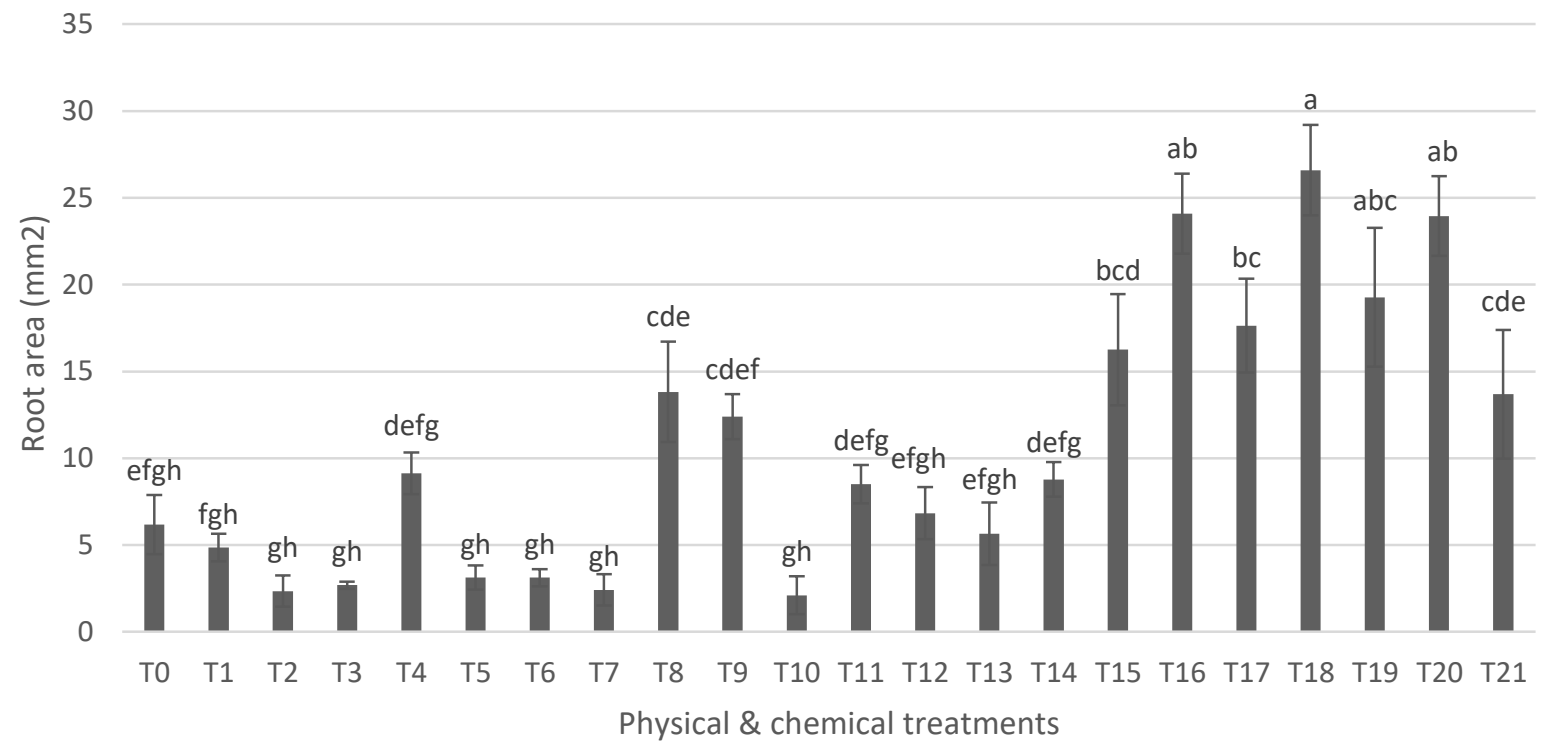

Fig. 4. Effects of different seed treatments on root area of 5-month old seedlings of Gleditsia caspica. $\mathrm{T}_{0}$ : control; $\mathrm{T}_{1}-\mathrm{T}_{6}$ : soaking in tap water for 1 to 6 days; $\mathrm{T}_{7}-\mathrm{T}_{9}$ : soaking in hot water 40,80 , and $100{ }^{\circ} \mathrm{C} ; \mathrm{T}_{10}$ : seeds coat removal; $\mathrm{T}_{11}-\mathrm{T}_{14}$ : immersion in $\mathrm{KNO}_{3}(1 \%)$ for $12,24,48$ and 72 hours; $\mathrm{T}_{15}-\mathrm{T}_{21}$ : immersion in $\mathrm{H}_{2} \mathrm{SO}_{4}(98 \%)$ for 15, 30, 45, 60, 90, 120, and 150 minutes, respectively.

\section{Discussion}

Effect of different dormancy breaking treatments on germination characteristics

In the present research, the effects of different PY-breaking treatments of Caspian locust seeds were determined at the seed germination stage and for 5-month old seedlings. Six germination traits and nine traits of 5-month greenhouse grown seedlings were affected by the seed dormancy breaking treatments.

Soaking seeds in cold water for 1 to 6 days had no significant effect on increasing the germination percentage, germination rate, and seed vigor index. Unlike our present results, Merou et al. (2011) reported that seed immersion in tap water for 2 days resulted in $73 \%$ germi- 
nation of Albizia julibrissin seeds compared to $33 \%$ for control. They mentioned that this treatment caused the formation of fissures and cracks in the seed coat, which would promote imbibition of water.

Seed scarification with sulfuric acid was the most efficient treatment for breaking the PY of Caspian locust seeds, and $100 \%$ of the seeds germinated after 45 (90, 120 and 150) min of acid scarification. Acid scarification also increased the seed vigor index and germination rate. ZoGHI et al. (2011) applied seven treatments for breaking Caspian locust seed dormancy, including cold and warm stratification for 45 days, soaking in water at $60{ }^{\circ} \mathrm{C}$ and $3{ }^{\circ} \mathrm{C}$ for 2 and 48 hours, respectively, and immersion in concentrated sulfuric acid for 30,60, and 90 minutes. Their results indicated that the maximal seed germination percentages were relative to sulfuric acid treatments for 90 and 60 minutes followed by hot water treatment at $60{ }^{\circ} \mathrm{C}$, being $38.3 \%, 21.7 \%$, and $18.3 \%$, respectively. The reason behind the low seed germination reported by them, compared to that of the present research, can be attributed to both the different experimental conditions (planting the treated seeds in trays containing sterile sand and keeping them in a growth room under a temperature range of 20 $25^{\circ} \mathrm{C}$ ) and seed provenance. In this regard, Merou et al. (2011) also found that the seed coat of Albizia julibrissin became permeable when seeds were immersed in sulfuric acid for 2 hours, which increased germination from 33\% to $99 \%$. Our results are consistent with those obtained in other studies of Fabaceae species in which acid scarification made the seed coat water-permeable, thus allowing seeds to imbibe and germination (Orozco-Almanza et al., 2003; Hu et al., 2009; BABASHPOuR et al., 2011; Merou et al., 2011). The results of research on seeds of Acacia auriculiformis (OLATUNJI et al., 2012) revealed that scarification with concentrated sulfuric acid for 5 and 10 minutes brought about the highest germination percentages (more than $92 \%$ ) compared to that of the control (42\%). Both the seed coat and the blocked natural openings are destroyed when the seeds are subject to sulfuric acid treatment. Acid scarification also was reported to expose the lumens of macro-sclereids in seed coat of Coronilla varia (BRANT et al., 1971). Acid scarification could, to some extent, destroyed the counter palisade cells of the seed hilum, which increased water absorption through the resulting opening of the seed hilum. In general, proper treatment with sulfuric acid has been demonstrated to open the plugged natural openings of seed coat, thus increasing the water absorption and gas exchange between placenta and its surrounding atmosphere. This, in turn, improves germination of seeds with PY (Li et al. 1999; RAHNAMA-GHAHFAROKHI and TAVAKKOL-AFSHARI, 2007; BASKIN and BASKIN, 2014; Purohit et al., 2015).

\section{Seedling growth after dormancy break}

Among the treatments used in this study, seed coat removal resulted in seedlings with the poorest growth, i.e. minimal rates of growth and morphological parameters in the 5-month old seedlings. Although seed coat removal had a more favorable effect on germination, as compared to the other physical treatments of breaking dormancy, it resulted in minimal shoot length, root and shoot mass, collar diameter, leaf area, and root area. Seed coat removal should have a similar effect as acid scarification in that the inhibition for water uptake is eliminated. However, since the embryo is suddenly exposed to ambient factors, it may be subjected to moisture stress. Also, embryo may be damaged while removing the seed coat.

Despite the fact that soaking seeds in hot water at room temperature had a positive effect on germination characteristics, it did not improve seedling growth performance compared with acid treatments. Considering the thick coat of Caspian locust seeds, and the better results of $\mathrm{T}_{9}$ (hot water $100{ }^{\circ} \mathrm{C}$ ) than the other water soaking treatments $\left(\mathrm{T}_{1}-\mathrm{T}_{8}\right)$, it seems that immersing seeds into boiling water for an increased period of time (e.g., 1-10 min) may bring about favorable germination and seedling growth. SOLIMAN and ABBAs (2013) demonstrated that scarification of Cassia fistula with sulfuric acid for 2 minutes followed by soaking in boiling water $\left(100^{\circ} \mathrm{C}\right)$ for 6 minutes was the best way to break seed dormancy, improving germination by $96 \%$ and producing seedlings with a high growth rate.

$\mathrm{KNO}_{3}$ is a chemical treatment that can be effective for breaking dormancy of water-permeable seeds of many species (Hartmann et al., 1997; ÇETINBAŞ and KoyUnCU, 2006). Since G. caspica seeds only had PY, the different levels of $\mathrm{KNO}_{3}$ treatment were not effective in increasing germination or seedling growth because the $\mathrm{KNO}_{3}$ was not absorbed by the embryo. Thus, the application of $\mathrm{KNO}_{3}$ was not beneficial for the studied species.

Although the highest rate of root length was seen in the control treatment, the different periods of acid scarification showed high rates as well. Also, immersion of Caspian locust seeds in concentrated sulfuric acid for 30 to 120 minutes had very positive effects on the other eight seedling traits. Shoot length, root and shoot mass, collar diameter, quality index, leaf number, leaf area, and root area of the 5-month old seedlings were the highest after seeds were treated with sulfuric acid. Each of these parameters can, per se, have a positive effect on the successful establishment of the produced seedlings used for afforestation practices. NourmoHAmmadi et al. (2016) found that the germination percentage of Caspian locust seeds (after seed dormancy breaking via physical and chemical treatments) was highly significantly correlated with DOI and sturdiness quotient (SQ). However, germination percentage has no significant correlation with shoot/root dry mass ratio (SRR). Further, mean germination time of Caspian locust seeds showed no significant correlation with DOI, SQ, SRR and Germination percentage. They suggested SQ and DOI as suitable indices for evaluating the qualitative status of the produced seedlings.

OlatunJ et al. (2012) found that scarification of Acacia auriculiformis seeds with concentrated sulfuric acid for 5 and 10 minutes brought about the highest germination percentages (more than $92 \%$ ) compared to that 
of the control $(42 \%)$. The highest values for shoot length and stem diameter were observed after seeds were treated in sulfuric acid for 5 and 10 minutes. The stimulatory and positive effects of scarification in (concentrated) sulfuric acid treatment on germination as well as growth traits have been reported for other species of Fabaceae, including Tamarindus indica (Muhammad and Amusa, 2003), Prosopis juliflora and P. koelziana (ZARE et al. 2011), and Centrosema pubescens (Rusdy, 2015). Soliman and ABBAS (2013) reported that the largest leaf area of well-grown Cassia fistula seedlings was observed following a combined treatment of scarification in concentrated sulfuric acid for 2 minutes and then soaking in hot water $\left(100^{\circ} \mathrm{C}\right)$ for $6 \mathrm{~min}$. The combined treatment had its most favorable effects on both germination parameters (germination rate and percentage and SVI) and the growth traits of C. fistula seedlings (plant height and dry mass, root length, and leaf number) during the first and second growth seasons of this species.

RUSDY (2017) also found that amongst the different conducted treatments such as soaking in boiling $\left(80{ }^{\circ} \mathrm{C}\right)$ water for $2,4,6$, and 8 hours, seed coat clipping as well as scarification in concentrated sulfuric acid $(4,8,12,16$, 20, 24, and 28 minutes), the latter treatment (applied for 20 minutes) showed optimal effects on germination (emergence index and percentage) and growth traits (dry biomass, number of leaves, and plant height) of the seedlings of Leucaena leucocephala.

Acid scarification of Fabaceae seeds with PY has an increasingly favorable effect on germination and even growth traits up to an optimal period of time, thereafter longer immersion times show adverse effects (Tables 1 and 2) due to damage of the embryo, which impedes further radical and seedling growth (OLATUNJI et al., 2012; KARAGUZEL et al., 2004). The optimum acid scarification time for breaking seed dormancy and promoting growth of $\mathrm{Lu}$ pinus varius was for 12 and 16 hours (KARAGUZEL et al., 2004). The optimum acid scarification time for breaking PY was 30-60 minutes for L. texensis (DAvis et al., 1991) 90-120 minutes for L. havardii (MACKAY et al., 1995) and 45 minutes for L. perennis (MACKAY et al., 1996) and 60 minutes for L. hispanicus (CENTENERA et al., 1999).

To know which of the available seedlings has the best chance for growth in natural sites can be crucially important for the restoration of devastated forests in terms of economic and management considerations. Thus far, a number of indices have been proposed for assessing the quality of the produced seedlings based on their growth and morphological properties (e.g., SRR, SQ, and DQI), among which DQI or Dickson's quality index is well known as one of the best (BinOtTo et al., 2010). This index can help researchers find the best (most suitable) seed provenance as well as the optimal growth efficiency of the produced seedlings (BAYAla et al., 2009; BinotTo et al., 2010; Nourmohammadi et al., 2016). The results of the present research demonstrated that sulfuric acid treatment holds also the potential to increase the DQI index by 3 -fold as compared to that of the control.

\section{Conclusions}

Although some physical and chemical treatments can break PY, a thorough understanding of their effects on the other stages of seedling growth is of great importance. Considering the results of the present research, it can be seen that seed immersion in sulfuric acid for 60 min is the best treatment for both improving the germination factor and producing healthy, high quality seedlings. Sulfuric acid treatment (30 to 120 minutes; optimally for 60 minutes) can thus be applied for producing strong and high quality seedlings. Seed coat removal or treatment with sulfuric acid greatly increased germination percentages, but after 5 months of growth seedlings from acidscarified seeds were larger and healthier than those from coat-removed seeds. In spite of the adverse environmental effects of sulfuric acid treatments, acid scarification can be considered as a practical alternative for producing quality seedlings of Fabaceae.

\section{Conflict of interest}

The authors declare that they have no conflict of interest.

\section{References}

Babashpour, M., Sharivivash, R., Rahbari, A., 2011. Effect of different treatments on seed germination of honey locust (Gleditschia triacanthos). Modern Applied Science, 5: 200-204.

BAskin, J.M., BASKIn, C.C., 2004. A classification system for seed dormancy. Seed Science Research, 14 (1): 1-16.

Baskin, J.M., BAskin, C.C., 2014. What kind of seed dormancy might palms have? Seed Science Research, 24 (1): 17-22. https://doi.org/10.1017/ S0960258513000342

Bayala, J., Dianda, M., Wilson, J., Ouedraogo, S.J., SANON, K., 2009. Predicting field performance of five irrigated tree species using seedling quality assessment in Burkina Faso, West Africa. New Forests, 38 (3): 309-322. doi: 10.1007/s11056-009-9149-4

Binotto, A.F., Lúcio, A.D.C., Lopes, S.J., 2010. Correlations between growth variables and the Dickson quality index in forest seedlings. Cerne, 16 (4): 457-464. doi: 10.1590/S0104-77602010000400005

Brant, R.E., McKee, G.W., Cleveland, R.W., 1971. Effect of chemical and physical treatment on hard seed of Penngift crownvetch. Crop Science, 11 (1): 1-6. doi:10.2135/cropsci1971.0011183X001100010001x

Centenera, E., De la Cuadra, C., Hill, G.D. 1999. Control of seed viability in Lupinus hispanicus. In HiLl, G.H. Towards the 21th century. Proceedings of the 8th 
International Lupin Conference, Asilomar, California, 11-16 May, 1996. Canterbury, New Zealand: International Lupin Association, p. 416-419.

Çetinbaş, M., Koyuncu, F., 2006. Improving germination of Prunus avium L. seeds by gibberellic acid, potassium nitrate and thiourea. Horticultural Science, 33 (3): 119-123.

Davis, T.D., George, S.W., Upadhyaya, A., Persons, J., 1991. Improvement of seedling emergence of Lupinus texensis Hook. following seed scarification treatments. Journal of Environmental Horticulture, 9 (1): $17-21$.

Dickson, A., Leaf, A.L., Hosner, J.F., 1960. Quality appraisal of white spruce and white pine seedling stock in nurseries. Forestry Chronicle, 36: 10-13. doi:10.5558/ tfc36010-1

Hartmann, H.T., Kester, D.E., Davies, F.T., Geneve, R.L., 1997. Plant propagation: principles and practices. Sixth edition. New Jersey: Prentice Hall. 770 p.

Hosseini, S.M., Kartoolinejad, D., Mirnia, S.K., Tabibzadeh, Z., Akbarinia, M., Shayanmehr, F., 2008. The European mistletoe effects on leaves and nutritional elements of two host species in Hyrcanian forests. Silva Lusitana, 16 (2): 229-237.

Hu, X.W., Wang, Y.R., Wu, Y.P., Baskin, C.C., 2009. Role of the lens in controlling water uptake in seeds of two Fabaceae (Papilionoideae) species treated with sulphuric acid and hot water. Seed Science Research, 19 (2): 73-80. https://doi.org/10.1017/S0960258509301099

IsTA, 2009. International rules for seed testing. The International Seed Testing Association, Bassersdorf.

Karaguzel, O., Cakmakci, S., Ortacesme, V., AydinoGLU, B., 2004. Influence of seed coat treatments on germination and early seedling growth of Lupinus varius L. Pakistan Journal of Botany, 36 (1): 65-74.

Kartoolinejad, D., Hosseini, S.M., Mirnia, S.K., AKBARINIA, M., Shayanmehr, F., 2007. The relationship among infection intensity of Viscum album with some ecological parameters of host trees. International Journal of Environmental Research, 1 (2): 143-149.

Li X., Baskin, J.M., Baskin, C.C., 1999. Anatomy of two mechanisms of breaking physical dormancy by experimental treatments in seeds of two North American Rhus species (Anacardiaceae). American Journal of Botany, 86 (11): 1505-1511.

MaCKAY, W.A., DAVIS, T.D., SANKHLA, D., 1995. Influence of scarification and temperature treatments on seed germination of Lupinus haverdii. Seed Science and Technology, 23: 815-821.

Mackay, W.A., Davis, T.D., Sankhla, D., RiemenschneIDER, D.E., 1996. Factors influencing seed germination of Lupinus perennis. Journal of Environmental Horticulture, 14 (4): 167-169

Merou, T., Takos, I., Konstantinidou, E., Galatsidas, S., VARSAMIS, G., 2011. Effect of different pretreatment methods on germination of Albizia julibrissin seeds. Seed Science and Technology, 39 (1): 248-252. https:// doi.org/10.15258/sst.2011.39.1.26
Miyase, T., MeleK, F.R., Warashina, T., Selim, M.A., El FiKI, N.M., KASSEM, I.A.A., 2010. Cytotoxic triterpenoid saponins acylated with monoterpenic acids from fruits of Gleditsia caspica Desf. Phytochemistry, 71 (16): 1908-1916. https://doi.org/10.1016/j.phytochem.2010.08.001

Muhammad, S., Amusa, N.A., 2003. Effects of sulphuric acid and hot water treatments on seed germination of tamarind (Tamarindus indica L.). African Journal of Biotechnology, 2 (9): 376-279.

Nourmohammadi, K., Rahimi, D., Naghdi, R., KarTOOLINEJAD, D., 2016. Effects of physical and chemical treatments of seed dormancy breaking on seedling quality index (QI) of Caspian locust (Gleditsia caspica Desf.). Austrian Journal of Forest Science, 133 (2): 157-171.

Olatunji, D., Maku, J.O., Odumefun, O.P., 2012. Effect of pre-treatments on the germination and early seedlings growth of Acacia auriculiformis Cunn. Ex. Benth. African Journal of Plant Science, 6 (14): 364 369. doi: 10.5897/AJPS11.255

Orozco-Almanza, M.S., De León-García, L.P., Grether, R., García-Moya, E., 2003. Germination of four species of the genus Mimosa (Leguminosae) in a semi-arid zone of Central Mexico. Journal of Arid Environments, 55 (1): 75-92. https://doi.org/10.1016/ S0140-1963(02)00265-3

Purohit, S., NAndi, S.K., Palni, L.M.S., Giri, L., Bhatt, A., 2015. Effect of sulfuric acid treatment on breaking of seed dormancy and subsequent seedling establishment in Zanthoxylum armatum DC: an endangered medicinal plant of the Himalayan region. National Academy Science Letters, 38 (4): 301-304. https://doi. org/10.1007/s40009-015-0349-5

Rahimi, D., Kartoolinejad, D., Nourmohammadi, K., NAGHDI, R., 2016. Increasing drought resistance of Alnus subcordata CA Mey. seeds using a nano priming technique with multi-walled carbon nanotubes. Journal of Forest Science, 62 (6): 269-278.

RAHNAMA-GHAHFAROKHI, A., TAVAKKOL-AFSHARI, R., 2007. Methods for dormancy breaking and germination of galbanum seeds (Ferula gummosa). Asian Journal of Plant Sciences, 6 (4): 611-616.

Rechinger, K.H., 1963-2001. Flora Iranica: Flora des Iranischen Hochlandes und der Umrahmenden Gebirge. Graz, Austria: Akademische Druck- u. Verlagsanstalt, 160: Caesalpiniaceae, 1986: 8 p.

RuSDY, M., 2015. Enhancing germination in seeds of Centrosema pubescens. International Journal of Scientific Research, 5 (10): 1-4.

RuSDY, M., 2017. Enhancement of seedling emergence and early growth of Leucaena leucocephala by hot water, mechanical and acid scarification pre-treatments. International Journal of Applied Environmental Sciences, 12 (5): 857-863.

Scharnweber, T., Rietschel, M., Manthey, M., 2007. Degradation stages of the Hyrcanian forests in southern Azerbaijan. Archiv für Naturschutz und Landschaftsforschung, 46 (2): 133-156. 
Schnabel, A., Krutovskil, K.V., 2004. Conservation genetics and evolutionary history of Gleditsia caspica: inferences from allozyme diversity in populations from Azerbaijan. Conservation Genetics, 5 (2): 195-204. https://doi.org/10.1023/B:COGE.0000030003.77703.c0

Soliman, A.S., ABbas, M.S., 2013. Effects of sulfuric acid and hot water pre-treatments on seed germination and seedlings growth of Cassia fistula L. American-Eurasian Journal of Agricultural \& Environmental Sciences, 13: 7-15. doi: 10.5829/idosi. aejaes.2013.13.01.1914

Soltani, E., Ghaderi-Far, F., Baskin, C.C., Baskin, J.M., 2016. Problems with using mean germination time to calculate rate of seed germination. Australian Journal of Botany, 63 (8): 631-635. http://dx.doi. org/10.1071/BT15133

Sozzi, G.O., Chiesa, A., 1995. Improvement of caper (Capparis spinosa L.) seed germination by breaking seed coat-induced dormancy. Scientia Horticulturae, 62 (4): 255-261. https://doi.org/10.1016/03044238(95)00779-S

Yousefi, S., Kartoolinejad, D., Bahmani, M., NaGHDI, R., 2017a. Effect of Azospirillum lipoferum and Azotobacter chroococcum on germination and early growth of hopbush shrub (Dodonaea viscosa L.) under salinity stress. Journal of Sustainable Forestry, 36 (2): 107-120. https://doi.org/10.1080/10549811.2 016.1256220
Yousefi, S., Kartoolinejad, D., Bahmani, M., NaGhdi, R., 2017b. Salinity tolerance of Dodonaea viscosa L. inoculated with plant growth-promoting rhizobacteria: assessed based on seed germination and seedling growth characteristics. Folia Oecologica, 44 (1): 2027. https://doi.org/10.1515/foecol-2017-0003

Yousefzadeh, H., Saidi, A., TAYebi, S., Kartoolinejad, D., NAGHDI, R., 2017. Molecular approach to determine taxonomic status of Septoria sp. causing leaf blotch of Castanea sativa in Hyrcanian forests. Journal of Forestry Research, 28 (4): 661-670. https://doi. org/10.1007/s11676-016-0363-6

Zare, S., Tavili, A., Darini, M.J., 2011. Effects of different treatments on seed germination and breaking seed dormancy of Prosopis koelziana and Prosopis Juliflora. Journal of Forestry Research, 22 (1): 35-38. https://doi.org/10.1007/s11676-011-0121-8

Zarinjoei, F., Rahmani, M.S., Shabanian, N., 2014. In vitro plant regeneration from cotyledon-derived callus cultures of leguminous tree Gleditsia caspica Desf. New Forests, 45 (6): 829-841. doi: 10.1007/s11056014-9440-X

Zoghi, Z., Azadfar, D., Kooch, Y., 2011. The effect of different treatments on seeds dormancy breaking and germination of caspian locust (Gleditschia caspica) tree. Annals of Biological Research, 2 (5): 400-406.

Received March 23, 2019

Accepted August 2, 2019 